\title{
Influence Factor Analysis on Strength of Lime-Fly Ash Loess
}

\author{
Yufen Zhang ${ }^{1}$, Zhiquan Zhang ${ }^{2}$ \\ ${ }^{1}$ College of Architecture and Civil Engineering, North China University of Technology, Beijing, China \\ ${ }^{2}$ School of Civil Engineering, Chang'an University, Xi'an, China \\ Email: yufenzh@gmail.com,zzqca@163.com
}

Received April 19, 2013; revised May 21, 2013; accepted May 30, 2013

Copyright (c) 2013 Yufen Zhang, Zhiquan Zhang. This is an open access article distributed under the Creative Commons Attribution License, which permits unrestricted use, distribution, and reproduction in any medium, provided the original work is properly cited.

\begin{abstract}
Lime-fly ash loess is composed of fly ash, lime and loess. It is a new material in subgrade backfill. Main factors to influence the strength of lime-fly ash loess are age, amount of fly ash and lime, ratio of fly ash to lime $(1: \mathrm{K})$, and moisture content. In order to observe the effect of each factor influencing the strength of lime-fly ash loess and find out the relationship between each other, this paper adopted orthogonal test design to conduct unconfined compression tests. The result shows that 90d strength can be considered to calculate the strength of lime-fly ash loess in practice. And the most important factor to influence the 90d strength of lime-fly ash loess is the amount of fly ash and lime, the second is moisture content, and then is the ratio of fly ash to lime (1:K). These achievements are significant to the design and application of lime-fly ash loess in subgrade construction of loess areas.
\end{abstract}

Keywords: Lime-Fly Ash Loess; Influencing Factors; Unconfined Compression; 90d Strength

\section{Introduction}

Loess with special mechanical property, is widely distributed in China. Especially in highway construction of China West, it is inevitable to encounter the problem of loess soil. Lime is very cheap materials and widely used to stabilize the loess, and this method has been used for more than thousand years. Recently, many scholars have studied the mechanism of stabilizing soil and the microreaction mechanism between lime and soil [1,2], and some important achievements have been obtained. Fly ash is the combustion leavings of fine-grinded coal in power generation. It is a potentially active volcanic ash material. Lime-fly ash loess can be used in road engineering, is a kind of backfilled earth mixed with fly ash, lime and loess. Zhang et al. [3], Li et al. [4] and Yang et al. [5] did some research on the strength increasing process and discipline of lime-fly ash loess. Ovando-Shelley and Perez [6] made a study of the influence of moisture content decreasing or increasing on undrained behavior of clayey sands by triaxial tests. Therefore, fly ash was used in highway engineering in place of traditional dirt or plain earth in China. The project quality was improved, at the same time fly ash, an original waste material, was turned into wealthy material so that lime and soil were saved.
However, fly ash has not been widely used in the loess roadbed engineering. The main reason is that strength formation of lime-fly ash loess is a complex process [7]. From a macro point of view, fly ash, lime and soil are mixed to a dense material with some initial strength and integrity after compaction. To the micro, the fly ash contains a lot of active silica $\left(\mathrm{SiO}_{2}\right)$, aluminum oxide $\left(\mathrm{Al}_{2} \mathrm{O}_{3}\right)$, iron oxide $\left(\mathrm{Fe}_{2} \mathrm{O}_{3}\right)$, and a small amount of acidic substances such as calcium oxide $(\mathrm{CaO})$ and so on. The content of the first three kinds of oxide is generally about $80 \%$. Soil also contained non-qualitative substances, such as $\mathrm{SiO}_{2}, \mathrm{Al}_{2} \mathrm{O}_{3}$ and other, and the main component of slaked lime is calcium hydroxide $\left(\mathrm{Ca}(\mathrm{OH})_{2}\right)$. After mixture, the three materials have a series of hydration reaction under certain moisture content, a series of waterinsoluble crystalline resultant stability will be hydrated like calcium silicate hydrate $\left(\mathrm{CaO} \cdot \mathrm{SiO}_{2} \cdot \mathrm{nH}_{2} \mathrm{O}\right)$, calcium aluminate $\left(\mathrm{CaO} \cdot \mathrm{Al}_{2} \mathrm{O}_{3} \cdot \mathrm{nH}_{2} \mathrm{O}\right)$, and hydrated calcium ferrite $\left(\mathrm{CaO} \cdot \mathrm{Fe}_{2} \mathrm{O}_{3} \cdot \mathrm{nH}_{2} \mathrm{O}\right)$. With the deepening of the hydration, more resultant generation are formed and gradually hardened in air and water. The solid particles among the lime mixture are cemented together to form a larger aggregate structure, so the strength of lime-fly ash loess is larger than any of its component material. This hydration process will continue until the reaction balances. Though 
it is relatively slow, the strength of lime is slowly growing with time. Therefore, this paper studies the strength pattern of lime-fly ash loess by unconfined compressive strength experiments. The research results can provide a theoretical basis and reference value in order that lime-fly ash loess will be used widely in the loess roadbed treatment.

\section{Unconfined Compressive Strength Test}

The test soil was taken from Tongguan, China. It was new accumulating loess with well-distributed and loose body; the fly ash was from Xiangfan Tianjian Industrial Co., Ltd. The main physical properties indicators of these two materials are shown in Tables $\mathbf{1}$ and $\mathbf{2}$ respectively. The lime in the test, was fresh, dry and strong active. There are many factors to influence strength of lime-fly ash loess, and it is very important to study the various factors and the relationship between each other. So in this test, orthogonal experimental design was conducted to find a better combination of these factors with the minimum test times.

The selected factors and levels in this orthogonal experiment are shown in Table 3. Test soil samples were standard specimens with $40 \mathrm{~mm}$ in diameter and $100 \mathrm{~mm}$ in height. Four test groups were aged by 7 days, 28 days, 90 days, 180 days respectively, and the strength were defined as $7 d$ strength, 28d strength, 90d strength and $180 \mathrm{~d}$ strength. Strain controlled compression apparatus was used in the test, and shear rates was controlled by 1 $\mathrm{mm} / \mathrm{min}$ and it was collected evenly according to the code of JTGE40-2007 [8], experimental results were analyzed by variance method. A desktop testing apparatus shown in Figure 1 was used for unconfined compressive strength test reported here.

\section{Characteristic Analysis of Test Results}

The test results of unconfined compressive strength of lime-fly ash loess are shown in Table 4, and variance analysis is shown in Table 5. Figure $\mathbf{2}$ is the strength trends lines. Every point of the trend lines is the average unconfined compressive strength on each factor respectively.

The following relationships can be reached based on the experimental and analytical investigation.

1) The unconfined compressive strength of lime-fly ash loess increased with age. The strength of every level lime-fly ash loess after 7 days is between $0.42 \mathrm{MPa}$ and $0.7 \mathrm{MPa}$, and the ratio of the maximum and minimum is 1.7. 28d strength is between 1.04 $\mathrm{MPa}$ and 2.21 MPa, and the ratio is 2.1 ; 90d strength is between $1.47 \mathrm{MPa}$ and $4.12 \mathrm{MPa}$, and the ratio is 2.8 ; $180 \mathrm{~d}$ strength is between $1.68 \mathrm{MPa}$ and $5.21 \mathrm{MPa}$, and the ratio is 3.1. Results show that the influence of all levels to the longterm strength is greater than to the early strength. Average unconfined compression strength is shown in the first one of Figure 2.

2) As can be seen from Figure 2, the amount of lime and fly ash has little impact on the $7 \mathrm{~d}$ strength, while the amount of lime and fly ash is mixed more than $20 \%$, a very significant impact on the late strength of lime-fly

Table 1. Indicators of physical properties of the soil.

\begin{tabular}{|c|c|c|c|c|c|c|}
\hline \multirow{2}{*}{ Specific gravity } & \multirow{2}{*}{ Plastic index } & \multirow{2}{*}{ Liquid limit (\%) } & \multirow{2}{*}{$>$} & \multicolumn{3}{|c|}{ Granulometric composition (\%) } \\
\hline & & & & $>0.05 \mathrm{~mm}$ & $0.05-0.005 \mathrm{~mm}$ & $<0.005 \mathrm{~mm}$ \\
\hline
\end{tabular}

Table 2. Indicators of physical properties of fly ash.

\begin{tabular}{|c|c|c|c|c|c|c|}
\hline \multirow{2}{*}{$\begin{array}{l}\text { Apparent density } \\
\qquad\left(\mathrm{g} / \mathrm{cm}^{3}\right)\end{array}$} & \multirow{2}{*}{$\begin{array}{l}\text { Max. dry density } \\
\qquad\left(\mathrm{g} / \mathrm{cm}^{3}\right)\end{array}$} & \multirow{2}{*}{$\begin{array}{l}\text { Optimized moisture content } \\
\text { (\%) }\end{array}$} & \multicolumn{4}{|c|}{ Main chemical composition (\%) } \\
\hline & & & $\mathrm{SiO}_{2}$ & $\mathrm{Al}_{2} \mathrm{O}_{3}$ & $\mathrm{Fe}_{2} \mathrm{O}_{3}$ & $\mathrm{CaO}$ \\
\hline 2.17 & 1.15 & 34.5 & 61.2 & 22.5 & 5.0 & 0.7 \\
\hline
\end{tabular}

Table 3. Factors and levels of unconfined compressive strength tests.

\begin{tabular}{|c|c|c|c|c|}
\hline \multirow{2}{*}{ Factors } & \multicolumn{4}{|c|}{ Levels } \\
\hline & 1 & 2 & 3 & 4 \\
\hline Amount of lime and fly ash (\%) & 10 & 20 & 30 & 40 \\
\hline Ratio of lime-to-fly ash (1:K) & $1: 1$ & $1: 2$ & $1: 3$ & $1: 4$ \\
\hline
\end{tabular}


Table 4. Results of unconfined compressive strength tests.

\begin{tabular}{|c|c|c|c|c|c|c|c|}
\hline \multirow{2}{*}{$\begin{array}{l}\text { Samples } \\
\text { number }\end{array}$} & \multirow{2}{*}{$\begin{array}{c}\text { Amount of lime and fly } \\
\text { ash (\%) }\end{array}$} & \multirow{2}{*}{$\begin{array}{l}\text { Ratio of lime-to-fly ash } \\
\qquad(1: \mathrm{K})\end{array}$} & \multirow{2}{*}{ Moisture content (\%) } & \multicolumn{4}{|c|}{ Test results (MPa) } \\
\hline & & & & $7 d$ & 28d & $90 d$ & $180 \mathrm{~d}$ \\
\hline S1 & $1(10)$ & $1(1: 1)$ & $4(28)$ & 0.47 & 1.48 & 1.68 & 1.88 \\
\hline S2 & $2(20)$ & $1(1: 1)$ & $1(17)$ & 0.50 & 1.58 & 2.31 & 2.46 \\
\hline S3 & $3(30)$ & $1(1: 1)$ & $3(24)$ & 0.58 & 2.06 & 3.98 & 4.96 \\
\hline S4 & $4(40)$ & $1(1: 1)$ & $2(21)$ & 0.63 & 2.17 & 4.12 & 5.21 \\
\hline S5 & $1(10)$ & $2(1: 2)$ & $3(24)$ & 0.57 & 1.72 & 2.46 & 3.00 \\
\hline S6 & $2(20)$ & $2(1: 2)$ & $2(21)$ & 0.61 & 1.69 & 2.23 & 2.63 \\
\hline S7 & $3(30)$ & $2(1: 2)$ & $4(28)$ & 0.44 & 1.56 & 1.89 & 2.20 \\
\hline S8 & $4(40)$ & $2(1: 2)$ & $1(17)$ & 0.42 & 1.56 & 3.03 & 3.36 \\
\hline S9 & $1(10)$ & $3(1: 3)$ & $1(17)$ & 0.45 & 1.04 & 1.56 & 1.68 \\
\hline S10 & $2(20)$ & $3(1: 3)$ & $4(28)$ & 0.51 & 1.15 & 1.56 & 1.77 \\
\hline S11 & $3(30)$ & $3(1: 3)$ & $2(21)$ & 0.70 & 2.04 & 2.58 & 2.96 \\
\hline S12 & $4(40)$ & $3(1: 3)$ & $3(24)$ & 0.67 & 2.21 & 3.63 & 3.92 \\
\hline $\mathrm{S} 13$ & $1(10)$ & $4(1: 4)$ & $2(21)$ & 0.53 & 1.32 & 1.47 & 1.87 \\
\hline S14 & $2(20)$ & $4(1: 4)$ & $3(24)$ & 0.59 & 1.34 & 1.99 & 2.04 \\
\hline S15 & $3(30)$ & $4(1: 4)$ & $1(17)$ & 0.49 & 1.19 & 1.74 & 2.15 \\
\hline S16 & $4(40)$ & $4(1: 4)$ & $4(28)$ & 0.51 & 1.45 & 2.35 & 2.53 \\
\hline \multicolumn{4}{|c|}{ Average unconfined compression strength } & 0.54 & 1.60 & 2.41 & 2.79 \\
\hline
\end{tabular}

Table 5. Variance analysis of the test results.

\begin{tabular}{|c|c|c|c|c|c|c|}
\hline Age & Variance source & $\begin{array}{c}\text { Deviation } \\
\text { quadratic sum }\end{array}$ & Variance & $\begin{array}{l}\text { Mean deviation quadratic } \\
\text { sum }\end{array}$ & F value & $\begin{array}{l}\text { Effect valuation } \\
\text { of strength }\end{array}$ \\
\hline \multirow{3}{*}{$7 d$} & Amount of lime and fly ash & 0.0073 & 3 & 0.0037 & 0.73 & Not significant \\
\hline & Ratio of lime-to-fly ash (1:K) & 0.0113 & 3 & 0.0056 & 1.13 & Not significant \\
\hline & Moisture content & 0.0753 & 3 & 0.0377 & 7.58 & Significant \\
\hline \multirow{4}{*}{$28 d$} & Amount of lime and fly ash & 0.5744 & 3 & 0.2872 & 4.70 & Moderate \\
\hline & Ratio of lime-to-fly ash $(1: \mathrm{K})$ & 0.5051 & 3 & 0.2525 & 4.13 & Moderate \\
\hline & Moisture content & 0.7939 & 3 & 0.3696 & 6.50 & Significant \\
\hline & Error & 0.1221 & 6 & 0.0610 & - & - \\
\hline \multirow{3}{*}{$90 d$} & Ratio of lime-to-fly ash (1:K) & 2.6169 & 3 & 1.3084 & 12.57 & Significant \\
\hline & Moisture content & 3.0249 & 3 & 1.5124 & 14.53 & Significant \\
\hline & Error & 0.2082 & 6 & 0.1041 & - & - \\
\hline \multirow{4}{*}{$180 d$} & Amount of lime and fly ash & 7.1730 & 3 & 3.5865 & 7.71 & Significant \\
\hline & Ratio of lime-to-fly ash (1:K) & 4.6292 & 3 & 2.3146 & 4.97 & Significant \\
\hline & Moisture content & 4.9765 & 3 & 2.4883 & 5.35 & Significant \\
\hline & Error & 0.9306 & 6 & 0.4653 & - & - \\
\hline
\end{tabular}




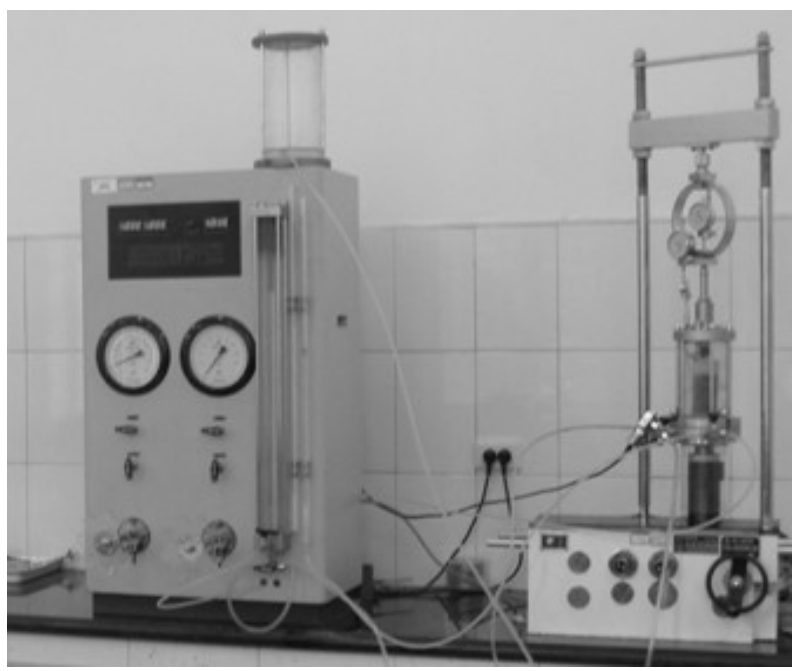

Figure 1. Testing apparatus.
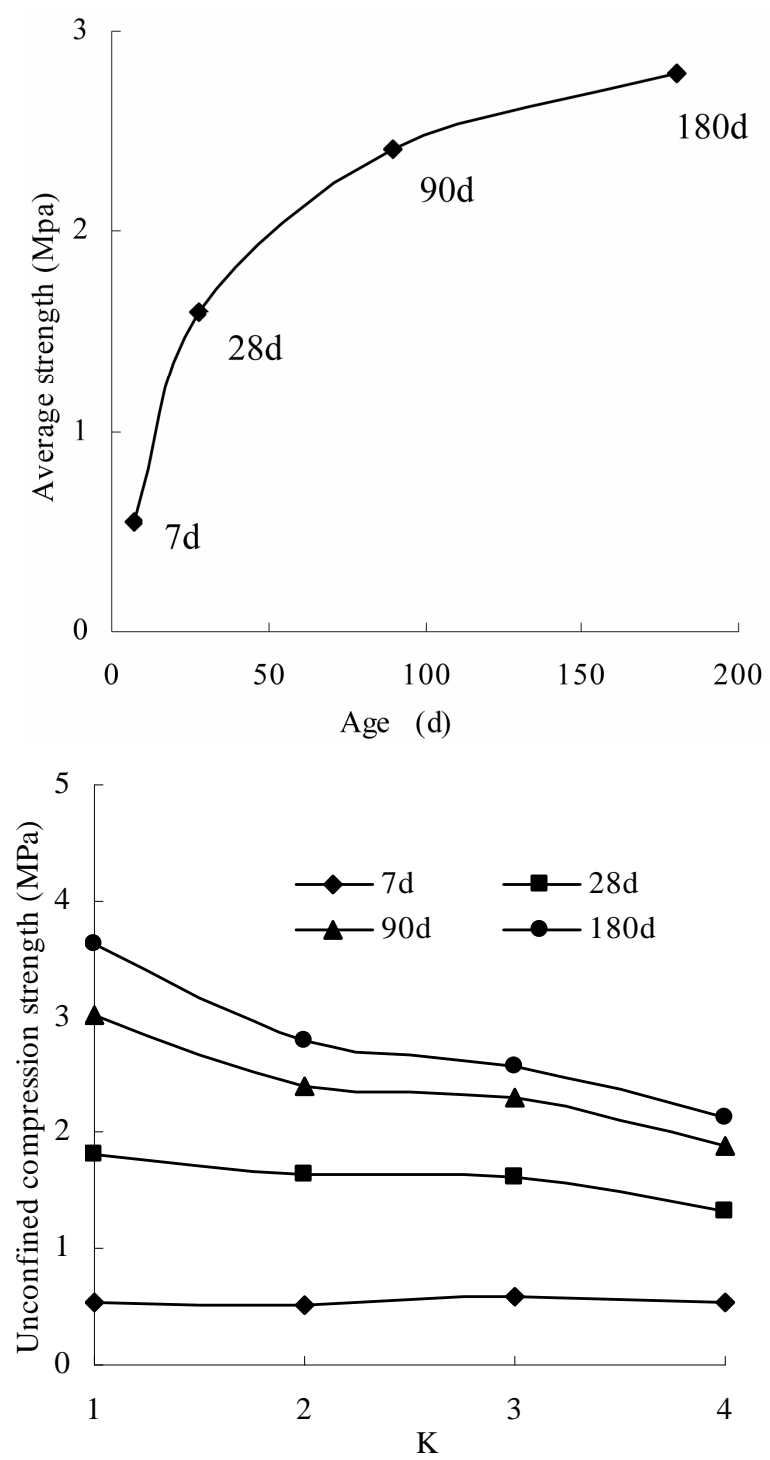

ash loess. Especially, the late unconfined strength of 90 days and 180 days can be increased significantly from $30 \%$ to $170 \%$ than the loess with a $10 \%$ amount of lime and fly ash. Some research also shows that the content of lime and fly ash should be larger than $25 \%$ in order that the soil is stabilized better [9]. Variance Analysis shows that the content of lime and fly ash is one of the primary factors mainly affecting the late strength (from 90 days to 180 days).

3) As for the Ratio of lime-to-fly ash (1:K), the streng th of lime-fly ash loess increases as $\mathrm{K}$ decreases. The main reason is that the calcium hydroxide plays a major role in the hydration reaction. When $\mathrm{K}$ is small, the reaction will fully proceed with adequate calcium hydroxide; on the contrary, if $\mathrm{K}$ is large, there is less calcium hydroxide to make the hydration reaction completely. Variance analysis shows that the Ratio of lime-to-fly ash is one of the
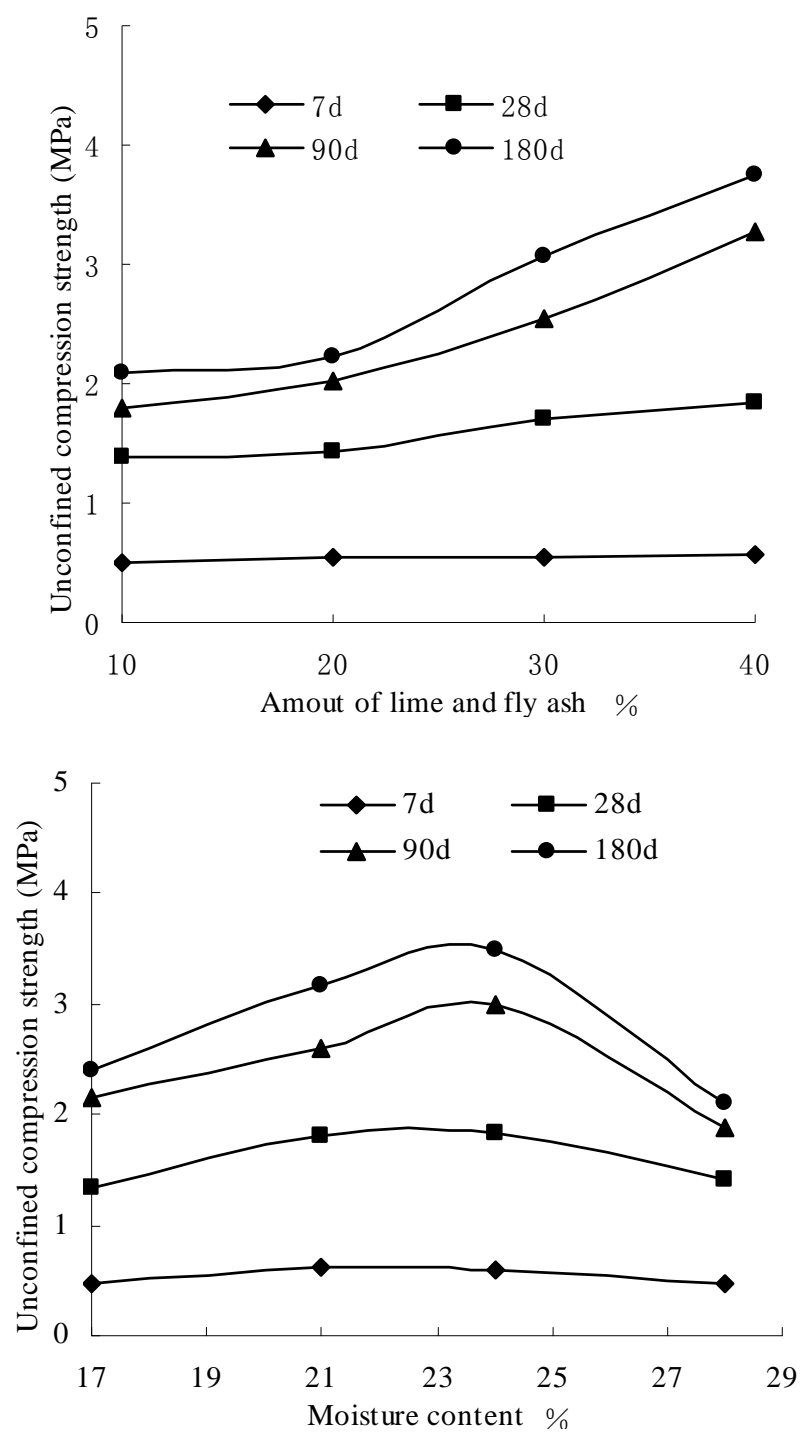

Figure 2. Strength trend lines of lime-fly ash loess. 
most important factors to affect the late strength (from 90 days to 180 days).

4) Strength of lime-fly ash loess increases firstly with the ascending moisture content, subsequently decreases. The reason is that the samples can be easily compact when moisture content is close to the optimum one, while the moisture content continues to increase, the compaction quality will decrease when the moisture content is more than the optimum one (almost from 20\% to $25 \%$ ), so the strength is decreasing. Variance analysis shows that the moisture content of the samples has significant influence on the early strength (from 7 days to 28 days) of lime-fly ash loess, and this strength effect was greater than other factors.

5) Generally, the early strength (from 7 days to 28 days) changes slowly with the changing parameters, while the late strength (from 90 days to 180 days) grows rapidly. It can be seen from Figure 2 that all the trend lines of $7 \mathrm{~d}$ strength is gentle and there is still a substantial increase in $28 \mathrm{~d}$ strength. $90 \mathrm{~d}$ strength and $180 \mathrm{~d}$ strength grows rapidly with the parameter changed. For there is no big difference between $90 \mathrm{~d}$ strength and $180 \mathrm{~d}$ strength, 90d strength can be considered to calculate the strength of lime-fly ash loess in practice. The following approximate relationship among 28d strength, 90d strength and $180 \mathrm{~d}$ strength can be written as

$$
\begin{aligned}
& f_{\mathrm{cu}, 28} \approx 0.57 f_{\mathrm{cu}, 180} \\
& f_{\mathrm{cu}, 90} \approx 0.86 f_{\mathrm{cu}, 180} .
\end{aligned}
$$

\section{Conclusion}

Unconfined compressive strength of lime-fly ash loess grows slowly with age. The marked factors to the early strength (from 7 days to 28 days) are moisture content, amount of lime and fly ash, and ratio of lime-to-fly ash(1:K). Variance analysis shows that the moisture content has significant influence on the strength of lime-fly ash loess, and there is optimum moisture content almost from $20 \%$ to $25 \%$. As K decreases, the strength of limefly ash loess increases. And the content of lime and fly ash is one of the primary factors mainly affecting the late strength (from 90 days to 180 days). In the strength evaluation, the strength of $90 \mathrm{~d}$ is more objective, can be considered to calculate the strength of lime-fly ash loess. And the most important factor to influence the $90 \mathrm{~d}$ strength of lime-fly ash loess is the amount of fly ash and lime, the second is moisture content, and then is the ratio of fly ash to lime (1:K).

\section{Acknowledgements}

The authors would like to acknowledge the support provided by the Chinese National Science Foundation (Grant No. 51008027) and the Special Fund for Basic Scientific Research of North China University of Technology, 2013.

\section{REFERENCES}

[1] X. B. Tu, A. K. L. Kwong, F. C. Dai, L. Tham and G. H. Min, "Field Monitoring of Rainfall Infiltration in a Loess Slope and Analysis of Failure Mechanism of RainfallInduced Landslides,” Journal of Engineering Geology, Vol. 105, No. 1-2, 2009, pp. 134-150. doi:10.1016/j.enggeo.2008.11.011

[2] H. L. Zhang and C. S. Hu, "Mechanical Properties Experiment of Compacted Loess-Lime,” Journal of Traffic and Transportation Engineering, Vol. 3, No. 4, 2003, pp. 13-16.

[3] T. T. Zhang, B. P. Zhang, Z. G. Tian and D. H. Lv, "Study on Engineering Characteristic of Lime-Fly Ash Loess," Chinese Journal Geotechnical Engineering, Vol. 26, No. 5, 2004, pp. 719-721.

[4] F. Q. Li, J. P. Yao, D. S. Zhao and G. Y. Chen, "The Experimental Study of Collapsibility and Mixture of Fly of Loess and Lime," Journal of Shenyang Jianzhu University (Natural Science), Vol. 21, No. 2, 2005, pp. 111113.

[5] Y. H. Yang, B .Liang and L. Ding, "Experimental Study on the Strength Behaviors of Fly Ash-Lime or Fly AshCement," Chinese Journal Geotechnical Engineering, Vol. 23, No. 2, 2001, pp. 227-230.

[6] E. Ovando-Shelley and B. E. Perez, "Undrained Behavior of Clayey Sands in Load Controlled Triaxial Tests," Geotechnique, Vol. 47, No. 1, 1997, pp. 97-111. doi:10.1680/geot.1997.47.1.97

[7] J. L. Zhang and B. J. Liu, "The Experimental Research on the Characteristic of Cement Loess," Journal of Xi'an Highway University, Vol. 19, No. 2, 1999, pp. 6-9.

[8] JTGE40-2007, "Test Method of Soils for Highway Engineering, China.”

[9] X. P. Zhang and Z. Q. Yu, "Experimental Study on Engineering Properties of Lime-Fly Ash Loess Mixture," Journal of Hohai University, Vol. 27, No. 3, 1999, pp. 5762. 